\title{
A study of the workability of natural hydraulic lime mortars and its influence on strength
}

\author{
R. Hanley $\cdot$ S. Pavía
}

Received: 15 June 2006/ Accepted: 16 April 2007

(C) RILEM 2007

\begin{abstract}
Lime mortars are currently used for both repairs to historic buildings and new construction. An important mortar property is workability. Lime mortars are often described as highly workable, however, due to the many variables contributing to workability, this is difficult to quantify. Workability largely depends on water content, and this will greatly affect compressive and flexural strengths, which in turn will determine the overall quality and durability of a mortar. The objective of this paper is to examine the relationship between workability and strength of naturally hydraulic lime (NHL) mortars in order to optimize their properties for a more efficient use in building. To this aim, mortars of several hydraulic strengths were mixed with different water contents in order to vary flow diameters and characterize workability. Compressive and flexural strength were then tested to measure the effect of the initial flow on the strength of the hardened mortar. This paper demonstrates that NHL 3.5 and 5 mortars require a flow value close to that of $185 \mathrm{~mm}$ prescribed by the European standards whereas NHL 2 mixes require a significantly lower value. This paper concludes that one universal flow value is inadequate when trying to optimize strength of NHL mortars and that, in order to optimize strength,
\end{abstract}

R. Hanley $\cdot$ S. Pavía ( $\square)$

Department of Civil, Structural and Environmental Engineering, Trinity College Dublin, Dublin 2, Ireland e-mail: pavias@tcd.ie mortars should be mixed to attain a different flow diameter for each hydraulic strength. However, other properties such as bond strength and water retention need to be considered before unique flow diameters are prescribed to lime mortars of different hydraulic strengths.

Résumé Les mortiers de chaux sont employés de nos jours tant dans le domaime de la restauration de bâtiments anciens que de la construction neuve. Une propriété essentielle d'un mortier est sa consistancel maniabilité. Les mortiers de chaux sont généralement décrits comme extrêmement «maniables». La difficulté est de donner une estimation quantitative de ce terme du fait de la multiplicité des facteurs mis en jeu et de l'absence d'essais normalisés. La maniablité d'un mortier de chaux dépend en grande partie de sa teneur en eau qui elle-même influence certaines propriétés comme le retrait ou la résistance à la compression et à la flexion, déterminant à leur tour la qualité et la durabilité du mortier. L'objectif de cet article est d'étudier la relation existant entre maniabilité et résistance mechanique d'un mortier de chaux hydraulique naturelle afin d'optimiser ses propriétés. Pour ce faire, des mortiers de chaux de résistance hydraulique et de teneurs en eau différentes ont été gâchés de façon à faire varier le diamètre d'écoulement initial et à caractériser la consistance. Des essais en compression et flexion ont été effectués pour étudier la résistance mechanique du mortier durci en fonction de l'écoulement initial. Les résul- 
tats obtenus indiquent que, alors que les mortiers de chaux NHL 3,5 et 5 demandent un écoulement initial proche de $185 \mathrm{~mm}$ comme recommandé par les normes européennes, ceux à base de NHL 2 exigent une valeur nettement inférieure. En vue d'optimiser leur résistance, les mortiers de chaux devraient donc être gâchés de façon à obtenir un diamètre d'écoulement spécifique à chaque chaux hydraulique employée. Ceci contredit la recommandation issues des normes de malaxage actuelles préconisant un diamètre d'écoulement initial unique quel que soit le type de chaux. Cependant, d'autres propriétés comme le retrait du matériau et l'adhérence à l'interface mortier-maçonnerie doivent être prises en compte avant de préconiser un diamètre d'écoulement spécifique à chaque mortier de chaux de résistance hydraulique donnée.

Keywords Natural hydraulic lime mortars . Workability - Water content - Initial flow · Compressive and flexural strength.

Mots-clés Mortier de chaux hydraulique naturelle . Maniabilité · Consistance . Teneur en eau . Écoulement initial - Résistance à la compression et à la flexion

\section{Introduction}

Mortars are a vital part of built structures, playing an important role structurally as well as in protecting buildings from decay. Lime mortars are currently used for both repairs to historic buildings and new construction. Most historic mortars were made using lime binders therefore lime mixes are recommended for repairs to historic buildings as they are generally more compatible in composition and physical properties with the existing masonry materials than artificial cement mixes [1-3]. Lime mortars allow moisture and vapor transfer; therefore, the transport of moisture in lime mortar-bonded masonry largely occurs through lime mortars. As a result, they weather through the dissolution of their carbonated lime binders and the crystallization of soluble salts within their pores [3], having a shorter lifespan than the masonry they hold together and requiring replacement [1].

Lime mortars possess physical properties that make them versatile building materials ideal for a wide range of applications. Lime mortars are plastic materials that provide high workability. In addition, they result in medium to high flexural bond strengths and possess reasonably high values of permeability and porosity [2]. A lime binder has the flexibility to cushion masonry joints to absorb strains and prevent cracking [3]. There are two characteristic types of lime: hydraulic and non-hydraulic. They differ in the manner by which they harden and in the properties they display. Hydraulic limes harden to a greater or lesser extent due to a chemical reaction between their active clay particles, lime and water (hydraulic set) whereas non-hydraulic limes harden due to both dehydration and carbonation (a reaction between the $\mathrm{CaO}$ in the lime binder and atmospheric $\mathrm{CO}_{2}$ ). Hydraulic limes can be natural or artificial. In both cases, they possess a range of degrees of hydraulic set. For example, feebly hydraulic limes harden mainly through carbonation but still achieve some degree of hydraulic set while eminently hydraulic mortars harden largely through hydraulic set. In general, a greater degree of hydraulic set will result in a stronger mechanical strength and lower permeability and flexibility [4].

Workability is a characteristic often defined by the mason. A workable mortar has a smooth, plastic quality, it is easily spread with a trowel and readily sticks to vertical surfaces. Lime mortars are often described as highly workable, however this description is a generality because there are no standardized tests to measure workability. The workability of a lime mortar largely depends on its water content and retention and internal friction, and these are closely related to properties such as porosity, size, shape and amount of aggregate and type and amount of binder. Due to these complex relationships, quantitative estimates of workability are difficult to obtain.

As aforementioned, water content is a main factor in workability and directly determines the initial flow of a mortar. New methods to test workability such as hand-held computerized devices to measure the rheology of a mortar are being developed [5, 6]. However, a convenient and standardized test is not yet in practice. Until a test is developed, measurements of water retention and initial flow must be relied upon to ensure satisfactory workability. A mortar with a higher water content will have a larger flow value than the same mortar with less water. The 
amount of water added to a lime mortar greatly affects the physical properties of the mix. An excess of water will undermine mechanical strength and raise the risk of mortar failure by shrinkage fracturing and leaching, reducing durability. In addition, workability and water content have an influence on both the aggregate-binder adhesion and the mortar's bond to the masonry units, which will determine the final mortar quality. Since mortars vary in aggregate composition, grading and water content as well as type and amount of binder, it is neither necessary nor desirable to specify water content of the mortar in order to establish a control over workability [7]. Rather, a more accurate way to ensure the correct amount of water is to specify the initial flow. The aim of this paper is to examine the relationship between workability and strength of hardened naturally hydraulic lime (NHL) mortars in order to optimize these properties for a more efficient use in building and restoration. To this aim, lime mortars of various water contents were tested for compressive and flexural strength, while workability was characterized by examining water content and initial flow.

\section{Materials and methods}

\subsection{Materials}

Three naturally hydraulic lime binders of different strength were used for mixing: a feebly hydraulic NHL 2, a moderately hydraulic NHL 3.5, and an eminently hydraulic NHL 5. A well-graded aggregate of siliceous composition, was used for all mortar mixes. The aggregate was passed through a sieve analysis in accordance with the requirements of BS EN 196-1:2005 [8]. The results of the sieve analysis are included in Table 1. According to the sieve analysis, the particle size distribution ranges within the limits specified by the standards [8].

\subsection{Mixing}

Nine types of mortar mixes were prepared and tested, three for each lime binder. All mortars were mixed with the same aggregate to lime ratio of $2.75: 1$ by mass for $20 \mathrm{~min}$. The lime and aggregate were mixed together before incrementally adding small amounts
Table 1 Results of sieve analysis showing aggregate grading

\begin{tabular}{lc}
\hline Sieve diameter $(\mathrm{mm})$ & Percent passing $(\%)$ \\
\hline 10 & 100.0 \\
5 & 90.0 \\
2.36 & 77.2 \\
1.18 & 62.1 \\
0.6 & 37.9 \\
0.3 & 2.4 \\
0.15 & 0.0 \\
\hline
\end{tabular}

of water until the desired consistency and workability were attained.

\subsection{Workability testing}

As aforementioned, water content is a main factor in workability and directly determines the initial flow of a mortar. Due to the complexity of factors affecting mortar workability, relating to the quality and amount of mortar aggregates and binders, a reliable way to ensure the correct amount of water that need to be added to a mortar is to specify an optimum initial flow. Initial flow is a measurement of the prepared mortar and thus takes into account the various variables affecting workability such as porosity, size and shape of aggregate, type of binder and relative proportions aggregate/binder. Specifying mortars by initial flow rather than water content allows the mason to ensure the final mix has the appropriate workability rather than a specific water content that may or may not correspond to a specific workability.

The initial flow was measured according to BS EN 459-2:2001 [9]. Each of the three lime binders were mixed with the appropriate amount of water to attain three specific values of initial flow: $165-\mathrm{mm}, 185-$ $\mathrm{mm}$, and 195-mm diameters. In order to determine the initial flow, a truncated cone mould was placed on the flow table and filled with freshly mixed mortar. The mould was then lifted away and the flow table mechanically raised $10-\mathrm{mm}$ and then dropped at a rate of once per second for $15 \mathrm{~s}$. During this test, the mortar will move outwards progressively increasing the flow diameter. The final diameter of the mortar (initial flow) was measured in millimeters. When the 
flow was too high, the sample was discarded and the mixing started over. When the flow was too low, water was added and the batch mixed for a further minute until the water was evenly distributed (the entire process lasted for approximately $1.5 \mathrm{~min}$ in order to avoid significant setting of lime). The flow test was then repeated.

\subsection{Curing}

Once the desired initial flow was achieved, the mortars were transferred to molds for curing in accordance with BS EN 196-1:2005 [8]. Once placed in the molds, the specimens were compacted using a vibration table. 50-mm cube specimens were cast for compressive strength tests and $40-\mathrm{mm} \times 40-\mathrm{mm} \times$ $160-\mathrm{mm}$ prisms for flexural strength tests. Curing was carried out according to EN 459-2 [9]. After an initial curing period of $8 \mathrm{~h}$ in standard laboratory conditions, specimens were covered with a damp cloth to restrict moisture loss in order to prevent fracturing by shrinkage. They were removed from their molds between 48 and $72 \mathrm{~h}$ later, depending on the speed of the initial set, and placed in a curing chamber at a temperature of $(20 \pm 2)^{\circ} \mathrm{C}$ and a relative humidity above $60 \%$.

\subsection{Determination of compressive strength}

Compression tests were conducted according to BS EN 196-1:2005 [8] with modifications from BS EN 459-2:2001 [9]. For each mortar type, 12 (50-mm) cube specimens were cast, 6 for testing after 28 days and 6 for 56-day testing. The equation below was used to determine compressive strength:

$R_{\mathrm{c}}=\frac{F_{\mathrm{c}}}{2500}$

where $R_{\mathrm{c}}$ is the compressive strength, in Newtons per square millimeters; $F_{\mathrm{c}}$ is the maximum load at fracture, in Newtons; 2,500 is the area of the cube face, in square millimeters $(50 \times 50)$. The mean of six readings was taken as the compressive strength and the coefficient of variance calculated.

\subsection{Determination of flexural strength}

Flexural strength tests were conducted according to BS EN 196-1:2005 [8] with modifications from BS

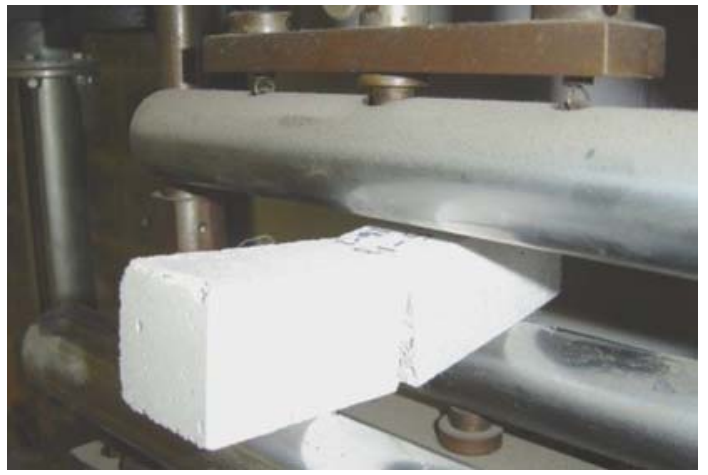

Fig. 1 Center-point loading method for determination of flexural strength

EN 459-2:2001 [9]. For each mortar type, six $(40 \times 40 \times 160-\mathrm{mm})$ rectangular prisms were cast, three for testing after 28 days and three for 56-day testing. The center-point loading method was used to determine the flexural strength. Here, the prisms were placed on two supporting rollers with the longitudinal axis normal to the supports and a load applied vertically to the opposite face of the prism by means of a loading roller. Figure 1 depicts the layout of the testing apparatus. After breaking the prism, the following equation was used to determine the flexural strength:

$R_{\mathrm{f}}=\frac{1.5 \times F_{\mathrm{f}} \times l}{b^{3}}$

where $R_{\mathrm{f}}$ is the flexural strength, in Newtons per square millimeters; $F_{\mathrm{f}}$ is the load applied to the middle of the prism at fracture, in Newtons; $b$ is the side of the square section of the prism, in millimeters; $l$ is the distance between the supports, in millimeters. The mean of six readings was taken as the strength and the coefficient of variance calculated.

\section{Results and discussion}

\subsection{Materials and mixing}

As aforementioned, according to the sieve analysis (Table 1), the particle size distribution ranges within the limits specified by the standard [8].

Difficulties experienced during mixing related to clumping of the NHL 2 mixes into spheres which were broken up by hand in order to ensure thorough 
mixing. Batches of NHL 3.5 and 5 did not clump as significantly; therefore, the question of whether the NHL 2 clumping was due to an excess of lime was examined. As aforementioned, all mortars were mixed by ratios according to mass, as per European standards, while site works and other standards prescribe mortar ratios according to volume. Proportioning by mass or by volume may imply an excess of either lime or aggregate and this not only affects workability but also influences mortar properties such as water demand, air content, shrinkage and mechanical strength [10]. Therefore, in order to compare proportioning materials by volume and by mass, masses were converted into volumes by dividing by the materials' densities and the resulting volumes compared with the original ratio of $2.75: 1$. The results of these calculations are shown in Table 2 .

According to these results, the ratio of aggregate to lime by volume is substantially lower than the original ratio of $2.75: 1$ by mass. Therefore, significantly more binder is used when prescribing proportions by volume than by mass, due to the fact that aggregate is denser than lime. This study proportioned mortars by mass therefore, according to the above, an excess of lime was not responsible for clumping. As it can be seen from Table 2, the ratios by volume differ by lime strength due to the variation of density by lime class. Therefore, when prescribing mortars by volume, the lower the density of the lime the higher the lime amount prescribed.

\subsection{Workability}

As aforementioned, workability is often a qualitative assessment of the mortar made by craftsmen and therefore, it is useful to describe the consistency of mortars verbally. Table 3 includes the relationship
Table 3 Relationship between initial flow, water content and workability of natural hydraulic limes

\begin{tabular}{|c|c|c|c|}
\hline $\begin{array}{l}\text { Mix by } \\
\text { binder }\end{array}$ & $\begin{array}{l}\text { Initial } \\
\text { flow (mm) }\end{array}$ & $\begin{array}{l}\text { Water } \\
\text { content } \\
(\%)\end{array}$ & Workability \\
\hline NHL 2a & 165 & 17.1 & Good; easy to work with \\
\hline NHL $2 b$ & 185 & 18.5 & $\begin{array}{l}\text { Quite runny; hard } \\
\text { to work with }\end{array}$ \\
\hline NHL 2c & 195 & 18.7 & $\begin{array}{l}\text { Extremely runny; very } \\
\text { difficult to work with }\end{array}$ \\
\hline $\begin{array}{l}\mathrm{NHL} \\
3.5 \mathrm{a}\end{array}$ & 165 & 13.0 & Slightly dry \\
\hline $\begin{array}{l}\mathrm{NHL} \\
3.5 \mathrm{~b}\end{array}$ & 185 & 15.4 & Slightly runny \\
\hline $\begin{array}{l}\mathrm{NHL} \\
3.5 \mathrm{c}\end{array}$ & 195 & 15.7 & $\begin{array}{l}\text { Quite runny; hard } \\
\text { to work with }\end{array}$ \\
\hline NHL 5a & 165 & 14.9 & Slightly dry \\
\hline NHL $5 b$ & 185 & 15.8 & Good; easy to work with \\
\hline NHL 5c & 195 & 17.0 & Slightly runny \\
\hline
\end{tabular}

between the initial flow and water content of the mixes tested and a verbal assessment of their workability. Water content is reported as the ratio of water to total mortar by mass, as described in BS EN 459-2:2001 [9].

According to the results in Table 3, the ideal water content for NHL 2 mixes occurs close to the initial flow of $165 \mathrm{~mm}$. Furthermore, these results suggest that the ideal water content for NHL 3.5 mixes falls somewhere between the initial flow of 165 and that of $185 \mathrm{~mm}$ (the $195 \mathrm{~mm}$ mix was overly wet and difficult to work with) while the NHL 5 results suggest that an optimal water content is close to the European standards' specification of $185 \mathrm{~mm}$. Also according to Table 3, the lower the lime hydraulicity the higher the amount of water required in order to reach a given initial flow.

Table 2 Comparison of proportions by volume and by mass

\begin{tabular}{|c|c|c|c|c|}
\hline Material type & $\begin{array}{l}\text { Aggregate:lime } \\
\text { ratio by mass }\end{array}$ & $\begin{array}{l}\text { Loose bulk density, } \\
\rho\left(\mathrm{g} / \mathrm{cm}^{3}\right)\end{array}$ & $\begin{array}{l}\text { Equivalent } \\
\text { volume }(\mathrm{m} / \rho)\end{array}$ & $\begin{array}{l}\text { Equivalent aggregate:lime } \\
\text { ratio by volume }\end{array}$ \\
\hline NHL 2 & $2.75: 1=1: 0.36$ & 0.53 & 1.88 & $1.76: 1.88=1: 1.06$ \\
\hline NHL 3.5 & & 0.67 & 1.49 & $1.76: 1.49=1: 0.84$ \\
\hline NHL 5 & & 0.75 & 1.33 & $1.76: 1.33=1: 0.75$ \\
\hline Aggregate & & 1.56 & 1.76 & \\
\hline
\end{tabular}


CCMA [7] advises that, in order to achieve an adequate consistency, mortar water content should be in the range of $11-16 \%$. According to this rule of thumb, the water requirement of the NHL 2 is higher than the advised range while the water contents of the remaining mortars, except for NHL 5c, fall within the advised range. However, the NHL 2 mortar with $17.1 \%$ water content possesses a good workability therefore the amount of water is correct. Therefore, although the CCMA rule is useful for identifying mixes that are clearly not of ideal water content, mortars close to the advised water range may not necessarily possess a good workability.

\subsection{Strength}

Table 4 presents the average 28 and 56-day compressive and flexural strengths of the NHL mortars with variable values of initial flow.

The relatively low values of COV suggest that the results obtained are valid (average COV's of 5.2$6.0 \%$ for the 28-day strength values and $6.6-7.0 \%$ for the 56-day values). However, there are a few exceptions of COV's over $10 \%$ which may indicate significant scatter, namely the $16 \% \mathrm{COV}$ of the NHL 3.5's 56-day flexural strength with a $195 \mathrm{~mm}$ initial flow. Figures 2 and 3 include the 28 and 56-day compressive and flexural strengths of the 9 mortar types. As it can be evidenced from these graphs, the mortars varied in strength with relation to initial flow.

It can be evidenced from these results that, in all mixes, the compressive strength increases over time while, except for the NHL 5 mixes, the flexural strength is maintained or slightly decreases. For both the NHL 2 and 3.5 mortars, a reduction of flexural strength usually occurs between the 28th and the 56th day indicating a decrease in plasticity and an increase in brittleness as the mortar hardens. The NHL 3.5 mixes experienced the greatest reduction in flexural strength over time.

Of the NHL 2 mixes, those with the lowest initial flow were the strongest in compression. However, the results do not show a specific initial flow value that yields increased flexural strength of NHL 2. For NHL 3.5 , the compressive strength of the three flow values were similar, with the $185 \mathrm{~mm}$ mix being slightly stronger than the other two. The interpretation of the flexural strength results is more challenging: by

Table 4 Flexural and compressive strength of the NHL mortars with variable values of initial flow

\begin{tabular}{|c|c|c|c|c|c|c|c|c|c|}
\hline Mix & $\begin{array}{l}\text { Initial } \\
\text { Flow } \\
(\mathrm{mm})\end{array}$ & $\begin{array}{l}\text { 28-day comp. } \\
\text { strength }\left(\mathrm{N} / \mathrm{mm}^{2}\right)\end{array}$ & $\begin{array}{l}\mathrm{COV} \\
(\%)\end{array}$ & $\begin{array}{l}\text { 56-day comp. } \\
\text { strength }\left(\mathrm{N} / \mathrm{mm}^{2}\right)\end{array}$ & $\begin{array}{l}\mathrm{COV} \\
(\%)\end{array}$ & $\begin{array}{l}\text { 28-day flexural } \\
\text { strength }\left(\mathrm{N} / \mathrm{mm}^{2}\right)\end{array}$ & $\begin{array}{l}\mathrm{COV} \\
(\%)\end{array}$ & $\begin{array}{l}\text { 56-day flexural } \\
\text { strength }\left(\mathrm{N} / \mathrm{mm}^{2}\right)\end{array}$ & $\begin{array}{l}\mathrm{COV} \\
(\%)\end{array}$ \\
\hline $\begin{array}{c}\text { NHL } \\
2\end{array}$ & 165 & 1.7 & 7 & 1.9 & 7 & 0.4 & 7 & 0.5 & 1 \\
\hline $\begin{array}{c}\text { NHL } \\
2\end{array}$ & 185 & 1.1 & 6 & 1.2 & 11 & 0.5 & 1 & 0.5 & 10 \\
\hline $\begin{array}{c}\text { NHL } \\
2\end{array}$ & 195 & 1.2 & 5 & 1.4 & 8 & 0.5 & 8 & 0.5 & 6 \\
\hline $\begin{array}{r}\text { NHL } \\
3.5\end{array}$ & 165 & 2.6 & 4 & 2.8 & 2 & 0.8 & 5 & 0.7 & 9 \\
\hline $\begin{array}{r}\mathrm{NHL} \\
3.5\end{array}$ & 185 & 2.8 & 5 & 3.0 & 6 & 0.9 & 7 & 0.7 & 7 \\
\hline $\begin{array}{r}\text { NHL } \\
3.5\end{array}$ & 195 & 2.7 & 7 & 2.7 & 14 & 0.6 & 3 & 0.5 & 16 \\
\hline $\begin{array}{c}\text { NHL } \\
5\end{array}$ & 165 & 3.2 & 5 & 4.0 & 6 & 0.9 & 4 & 0.9 & 3 \\
\hline $\begin{array}{c}\text { NHL } \\
5\end{array}$ & 185 & 4.0 & 8 & 4.9 & 5 & 1.0 & 6 & 1.1 & 5 \\
\hline $\begin{array}{c}\text { NHL } \\
5\end{array}$ & 195 & 3.1 & 8 & 3.4 & 5 & 0.9 & 7 & 1.1 & 2 \\
\hline
\end{tabular}

$\mathrm{COV}=$ coefficient of variation 
Fig. 2 Compressive strength of NHL mortars with different values of initial flow
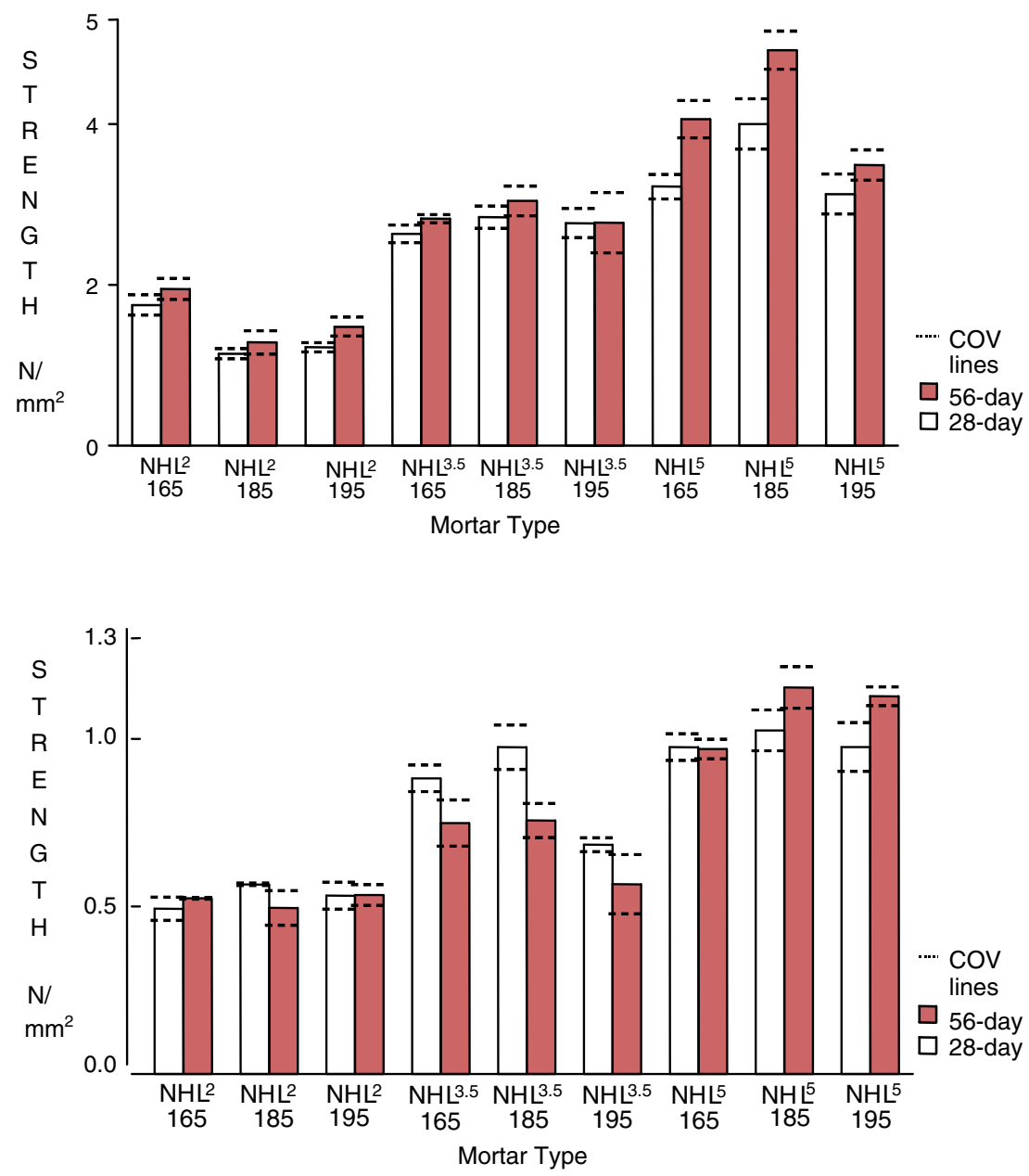

Fig. 3 Flexural strength of NHL mortars with different values of initial flow considering just 28-day flexural strength, the $185 \mathrm{~mm}$ initial flow is the best, producing the strongest mix. This result is consistent with the flow value specified European testing standards. In contrast, by considering the 56-day flexural strength, the $165 \mathrm{~mm}$ flow mix is the strongest. In relation to the NHL 5 mortars, compressive strength results indicate that the $185 \mathrm{~mm}$ initial flow mix is significantly stronger at both the 28 and the 56 day. For the flexural strength tests the results of the three mixes are similar, yet the $185 \mathrm{~mm}$ initial flow mix is slightly stronger at both the 28 and the 56 day. Therefore both compressive and flexural strength results indicate that an initial flow of $185 \mathrm{~mm}$ is more suitable for optimizing strength of NHL 5 than either $165 \mathrm{~mm}$ or $195 \mathrm{~mm}$.

The results above agree with the compressive strength limits set by current European standards (Table 5) [11]. For example, of the NHL 2 mixes, only the $165 \mathrm{~mm}$ initial flow mix tested falls within the limit range required by the standard, the other two mixes being too weak. While, also according to the current standard strength limits, of the NHL 3.5 mixes, the $165 \mathrm{~mm}$ initial flow mix is too weak, and so are the NHL 5's of 165 and $195 \mathrm{~mm}$ initial flow.

When considered as a whole, these results suggest that one universal flow value for natural hydraulic lime mortars is inadequate when trying to optimize strength (see Table 6). It seems clear that NHL 2 mixes require a significantly lower value of initial flow, whereas NHL 3.5 and 5 mixes appear to require a value close to the $185 \mathrm{~mm}$ prescribed by the European standards [9]. In particular, the ideal flow value for NHL 5 agrees with that specified, by the European standards as compressive and flexural strength results indicate that an initial flow of 
Table 5 Limits for 28-day compressive strength set by EN 459 [11]

\begin{tabular}{lll}
\hline Binder & Lower limit $\left(\mathrm{N} / \mathrm{mm}^{2}\right)$ & Upper limit $\left(\mathrm{N} / \mathrm{mm}^{2}\right)$ \\
\hline NHL 2 & 1.5 & 10 \\
NHL 3.5 & 2.7 & 14 \\
NHL 5 & 4.0 & 20 \\
\hline
\end{tabular}

Table 6 Initial flows resulting in best workability and strength by lime class

\begin{tabular}{clll}
\hline Binder & $\begin{array}{l}\text { Initial flow } \\
(\mathrm{mm}) \text { that } \\
\text { gives best } \\
\text { workability }\end{array}$ & $\begin{array}{l}\text { Initial flow } \\
\text { resulting in best } \\
\text { compressive } \\
\text { strength }\end{array}$ & $\begin{array}{l}\text { Initial flow } \\
\text { resulting in best } \\
\text { flexural strength }\end{array}$ \\
\hline $\begin{array}{c}\text { NHL } \\
2\end{array}$ & 165 & 165 & $\begin{array}{l}\text { Results do not } \\
\text { show a specific } \\
\text { flow value that } \\
\text { optimizes flex. } \\
\text { strength }\end{array}$ \\
& & & $\begin{array}{c}185 \text { at d. 28, 165 } \\
\text { at d. } 56\end{array}$ \\
NHL & $165-185$ & 185 & 185 \\
3.5 & & 185 & \\
NHL & 185 & & \\
5 & & & \\
\hline
\end{tabular}

$185 \mathrm{~mm}$ is more suitable for optimizing strength of NHL 5 than either 165 or $195 \mathrm{~mm}$.

\section{Conclusions}

The European standards for mixing lime mortars specify one single value for initial flow for lime mortars $(185 \pm 3 \mathrm{~mm})$. However, the results of this study suggest that one universal value for flow is inadequate for the various NHL mortars. The results suggest that each NHL type has a unique water content and initial flow that maximizes strength with an appropriate level of workability. This research concludes that, for the NHL 2 mixes, an optimal initial flow is closer to $165 \mathrm{~mm}$ than the $185 \mathrm{~mm}$ prescribed by current testing standards while the NHL 3.5 and 5 mortars require a value close to the $185 \mathrm{~mm}$ prescribed by European standards. This paper concludes that more tests need to be carried out in order to determine the ideal initial flow value that optimizes each NHL strength. For example, properties such as water retention and bond strength need to be considered before unique flow diameters are prescribed for lime mortars of different hydraulic strengths. Other approaches may need to be developed, for example, using a rheometer to determine the viscosity and yield stress of the material might lead to a better correlation with the workability expressed by the craftsmen.

This paper also concludes that standards that call for proportioning lime mortars by volume prescribe more lime binder than those that call for proportioning by mass, and that the lower the lime hydraulicity (thus the density), the higher the lime amount prescribed. This needs to be noted when designing mortars because an excess of binder will increase water demand and this will improve workability simultaneously decreasing strength and increasing shrinkage and air content, and these in turn may adversely impact on mortar durability. However, on the question of whether proportioning lime mortars by mass is more desirable than by volume, there are other issues that need to be considered such as the convenience of proportioning by volume on site work.

Acknowledgments The authors would like to thank Dr. H. M. Schiffner, of the Institut für Kalk- und Mörtelforschung e. V., Köln, Convenor of CEN TC 51/WG 11/TG 1 for taking this research into consideration within the EN 459-2 framework. This research was funded by the US-Ireland Alliance under the G. J. Mitchell Scholarship 2004-05. Materials were graciously donated by St Astier Limes, France, and The Traditional Lime Company, Ireland. The testing was carried out in the Dept. of Civil, Structural and Environmental Engineering, Trinity College Dublin. The authors thank Mr. Chris O'Donovan, for facilitating our laboratory work; Mr. Martin Carney for his help with testing in the Soils Laboratory; Mr. Eoin Dunne for his assistance with testing in the Materials Laboratory and $\mathrm{Mr}$. Dave McAuley for building equipment. Their help is much appreciated. The authors also thank Ms. Luice Chevert for translating the abstract.

\section{References}

1. Ashurst J, Ashurst N (1988) Practical building conservation, vol 3, Mortars, plasters and renders. Gower Technical Press, Aldershot

2. Holmes S, Wingate M (1997) Building with lime: a practical introduction. 2nd edn. ITDG, London

3. Pavía S, Bolton J (2000) Stone, brick and mortar. Wordwell, Bray 
4. Pavía S, Treacy E (in press) A comparative study of the durability and behaviour of fat lime and feebly-hydraulic lime mortars. Mater Struct

5. Cullen R, West R (2004) The development of a rheology tool for characterising the rheological properties of fresh concrete. In: Mason SL (ed) Annual transactions of the Nordic Rheology Society, Iceland, vol 12, pp 71-78

6. Cullen R, West R (2005) Development of a hand-held rheology tool and suitable testing criteria. In: Dhir RK, Jones MR, Zheng L (eds) Proceedings of the 6th international congress: repair and renovation of concrete structures, Dundee, Scotland, 2005. Thomas Telford, London, pp 195-202
7. Carolinas Concrete Masonry Association. http://ccmaonline.com/NewPages/weather.html

8. BS EN 196-1 (2005) Methods of testing cement. Part 1. Determination of strength

9. BS EN 459-2 (2001) Building lime. Part 2. Test methods

10. Hanley RC (2006) The relationship between workability and bond strength of lime mortars. MSc Thesis, University of Dublin, Trinity College Dublin

11. BS EN 459-1 (2001) Building lime. Part 1. Definitions, specifications and conformity criteria 